\title{
Knowledge of Lassa Fever Disease and Its Risk Factors Among Rural People in a Nigerian Community ${ }^{\dagger}$
}

\author{
Abdulrazaq Abdullahi Gobir 1,*, Clara Ladi Ejembi ${ }^{~}$, Aliyu Abubakar Alhaji ${ }^{1}$, \\ Muhammad Bello Garba ${ }^{2}$, Chinedu John -Camillus Igboanusi 2, Bilkisu Usman ${ }^{2}$, \\ Zarah Zambuk Umar ${ }^{2}$ and Istifanus Anekoson Joshua ${ }^{2}$ \\ 1 Community Medicine Department, Ahmadu Bello University, Zaria 810211, Nigeria; \\ claraladiejembi@yahoo.co.uk (C.L.E.); alhajimph@gmail.com (A.A.A.) \\ 2 Community Medicine Department, Ahmadu Bello University Teaching Hospital, Zaria 810211, Nigeria; \\ muhbello02@gmail.com (M.B.G.); chinedujc@yahoo.com (C.J.-C.I.); bilkisuusman79@gmail.com (B.U.); \\ zarahzambuk@gmail.com (Z.Z.U.); dristifanus@yahoo.com (I.A.J.) \\ * Correspondence: aagobir@yahoo.co.uk \\ + Presented at the 5th African Conference on Emerging Infectious Diseases, Abuja, Nigeria, 7-9 August 2019. \\ Published: 21 May 2020
}

\begin{abstract}
Introduction: Lassa fever disease (LFD) is an acute viral haemorrhagic fever caused by Lassa virus. It is a disease of public health importance in West Africa and a global health threat. It is endemic in some West African countries like Benin, Ghana, Guinea, Liberia, Mali, Sierra Leone, and Nigeria, where an estimated 300,000 to 500,000 cases occur every year with an estimated 5000 annual deaths. Persons living in rural areas and health care workers are at greatest risk. Public awareness and knowledge of the LFD and its risk factors are some of the important factors that determine disease transmission and success of preventive/control efforts. This study was therefore conducted to assess LFD-related awareness and knowledge in Gangara, a rural agrarian community in Giwa Local Government Area of Kuduna State, NorthWest Nigeria. Methods: A cross-sectional, community based descriptive study conducted in Gangara community. An intervieweradministered questionnaire was used to collect data from 556 adult respondents, selected using systematic random sampling technique. Data was analyzed using SPSS (version 20). Results: A majority of the respondents were females $(52.9 \%)$ with a mean age of $37.0 \pm 15.2$. The level of awareness of LFD was high (66.7\%) among respondents and there was a statistically significant association between awareness of LFD and not having any form of education $(\mathrm{P}<0.00)$. However, most of the respondents (79.0\%) have poor knowledge of LFD. Knowledge of risk factors for LFD was also poor with $59.4 \%$ not knowing that drying grains and foodstuffs on the ground is a risk factor for LFD. Conclusions: Awareness of the disease was quite high but knowledge of the disease and its risk factors was poor. For effective prevention of future outbreaks, the community needs to be properly educated on LFD and its risk factors.
\end{abstract}

Keywords: knowledge; lassa fever disease; risk factors; rural; Nigeria

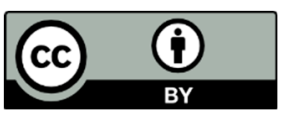

(C) 2020 by the authors. Licensee MDPI, Basel, Switzerland. This article is an open access article distributed under the terms and conditions of the Creative Commons Attribution (CC BY) license (http://creativecommons.org/licenses/by/4.0/). 